\title{
ARCHEOLOGIA PRADZIEJOWA WSCHODNIEGO ŚRÓDZIEMNOMORZA NA UNIWERSYTECIE IM. ADAMA MICKIEWICZA W POZNANIU
}

\author{
PREHISTORIC ARCHAEOLOGY OF THE EASTERN \\ MEDITERRANEAN AT ADAM MICKIEWICZ UNIVERSITY \\ IN POZNAŃ
}

\author{
Arkadiusz Marciniak \\ Instytut Prahistorii, Uniwersytet im. Adama Mickiewicza \\ ul. Św. Marcin 78, 61-809 Poznań, Poland \\ Arkadiusz Klimowicz \\ Çatalhöyük Research Project
}

\begin{abstract}
The paper aims at presenting research activities of prehistoric archaeologists from Adam Mickiewicz University in Poznań in the Eastern Mediterranean. In particular, it focuses on presenting objectives and results of ongoing works at the Neolithic settlement in Çatalhöyük in Central Anatolia. The Polish project, which is an intrinsic element of the Çatalhöyük Research Project, began in 2001 in cooperation with the Polish Academy of Sciences and later University of Gdańsk. It continues currently as the Adam Mickiewicz University project. The works involve excavating the uppermost levels of the settlement occupation dated back to the end of the seventh millennium cal. BC, which have not been investigated to date. The discovered architecture and material objects are unique in nature indicating remarkable transformations in all aspects of the long-lasted Neolithic tradition. The results have been published and presented in numerous national and international settings. They also led to establishing a close collaboration with numerous leading centres of the Anatolian and Near Eastern Neolithic studies. The project at Çatalhöyük comprises an active participation of students leading to completion of numerous Bachelor, Master and Doctorate dissertations.
\end{abstract}

\section{WSTĘP}

Pierwsza dekada XXI w. w dziejach Instytutu Prahistorii UAM przyniosła rozpoczęcie działalności badawczej we wschodniej strefie Morza Śródziemnego. Ten ogromny obszar, obejmujący północno-wschodnie i wschodnie wybrzeża Morza 
Śródziemnego, jest kolebką wielu pradziejowych, antycznych i wczesnohistorycznych cywilizacji. Nie może zatem dziwić, iż region ten cieszy się od lat niesłabnącym zainteresowaniem archeologów z całego świata i jest miejscem działania wielu misji badawczych. Archeologia nie byłaby dyscypliną w obecnym jej kształcie, gdyby nie działania tak znamienitych postaci, jak Kathleen Kenyon, John Garstang czy James Mellaart, którzy większą część swego zawodowego życia spędzili w regionie wschodniego Śródziemnomorza. Ich wieloletnie badania pozwoliły na wypracowanie kompleksowych schematów chronologicznych oraz wyznaczenie nowoczesnych standardów badań wykopaliskowych ${ }^{1}$.

Szczególne miejsce w omawianej strefie Morza Śródziemnego zajmuje Anatolia. Ten ogromny obszar posadowiony między Morzem Czarnym na północy, Morzem Śródziemnym na południu, oddzielony od obszarów Azji Centralnej masywem Zagros i Kaukazu stanowi naturalny pomost między obszarami Lewantu i Międzymorza a południowo-wschodnią Europą. Anatolia jest miejscem narodzin rodzimych cywilizacji Hetytów czy Urartu, ale i miejscem rozkwitu kultury hellenistycznej ${ }^{2}$. Ze względu na swe położenie geograficzne jest głównym obszarem dla zrozumienia charakteru i mechanizmu recepcji bliskowschodnich wzorców kulturowych w Europie, we wszystkich bez wyjątku okresach. Obszar Anatolii jest także kluczem do zrozumienia przemian zachodzących $\mathrm{w}$ okresie neolitu, w szczególności zaś $\mathrm{w}$ odniesieniu do procesu rozprzestrzeniania się zdobyczy wiązanych z tzw. rewolucją neolityczną na obszary Europy, co konwencjonalnie określane jest mianem neolityzacji ${ }^{3}$.

\section{ÇATALHÖYÜK I NEOLIT ANATOLII}

Nie ulega wątpliwości, że najważniejszym stanowiskiem neolitycznym w Anatolii jest Çatalhöyük (ryc. 1,2). Jest to monumentalny tell górujący nad Płaskowyżem Konijskim, który stanowi pozostałość ogromnego ośrodka o charakterze protomiejskim, zamieszkiwanego w okresie swego rozkwitu przez ok. kilka tysięcy mieszkańcówmieszkańców. Çatalhöyük, od momentu rozpoczęcia tam prac wykopaliskowych w początkach lat 60 . XX w., stanowi niezmiennie punkt odniesienia dla rekonstrukcji i zrozumienia skomplikowanych procesów zachodzących w tamtym okresie na terenie Bliskiego Wschodu i Europy ${ }^{4}$.

Możliwość prowadzenia badań wykopaliskowych na tym światowej rangi stanowisku przez zespół Instytutu Prahistorii UAM oznacza nie tylko udział w jednym z największych przedsięwzięć badawczych współczesnej archeologii, lecz także po-

\footnotetext{
${ }^{1}$ Np. Garstang 1953; Kenyon 1961, 1971, 1985; Mellaart 1975.

${ }^{2}$ Np. Lloyd 1956; Joukowsky 1996; Mellaart 1978; Sagona, Zimanski 2009.

${ }^{3}$ Np. Childe 1939, 1954; Gimbutas 1989, 1991; Hodder 1990; Lichter 2005.

${ }^{4}$ Mellaart 1967; Hodder 1987, 1990; Kuijt 2000.
} 


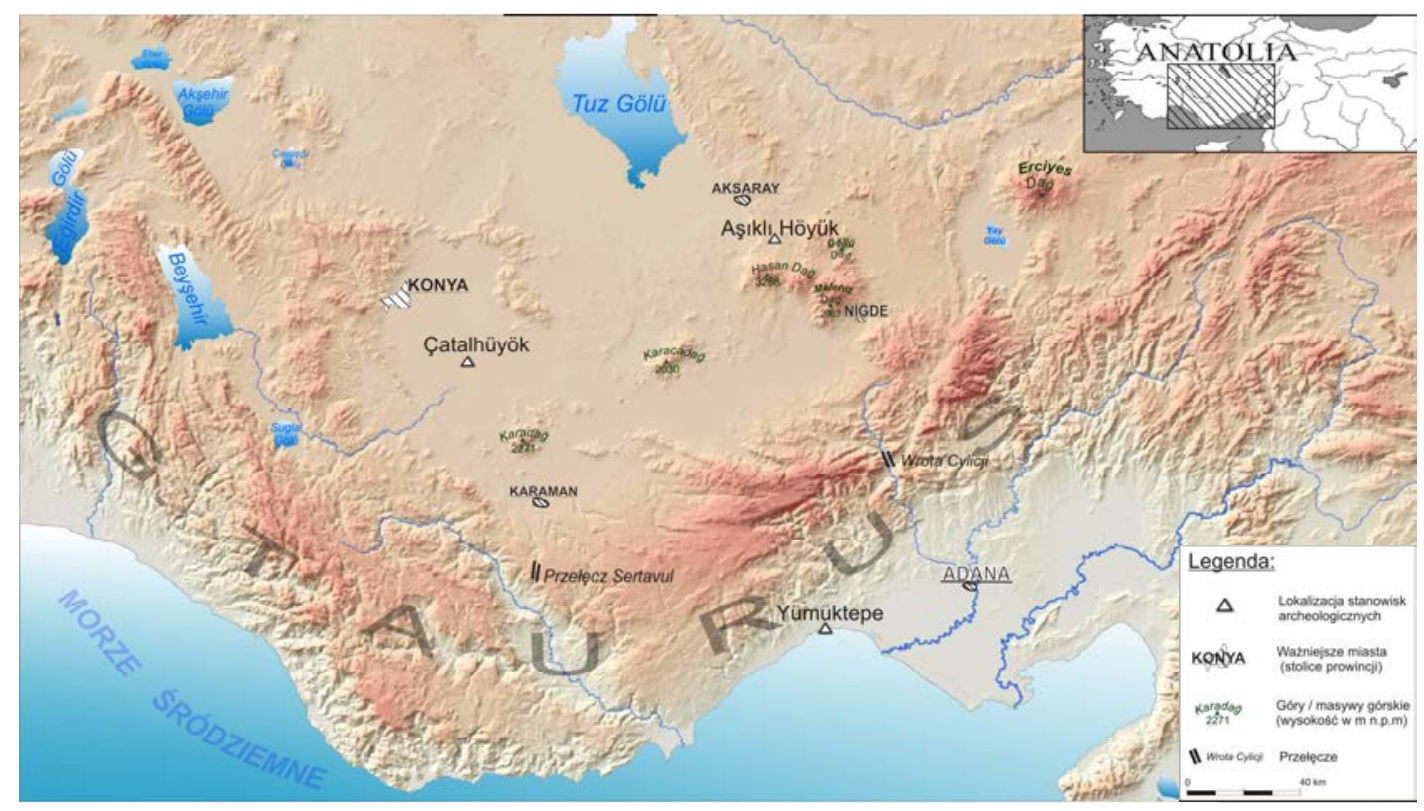

Ryc. 1. Lokalizacja Çatalhöyük i najważniejszych stanowisk archeologicznych w Środkowej Anatolii (oprac. A. Klimowicz)

Fig. 1. Çatalhöyük in the context of major archaeological sites in Central Anatolia (by A. Klimowicz)

pozwala na realizację nowatorskiej problematyki związanej bezpośrednio z szeroko rozumianą genezą neolitu europejskiego. Powstanie poznańskiej misji archeologicznej w Anatolii w 2000 r. i podjęte przez nią prace badawcze w Çatalhöyük były pierwszą inicjatywą badawczą Instytutu Prahistorii na obszarze Bliskiego Wschodu. Antycypowały one jednocześnie powstanie specjalności ,archeologia orientalna i klasyczna" w ofercie dydaktycznej Instytutu. Przez osiem lat stanowiła ona jedyny zespół badawczy Instytutu Prahistorii prowadzący badania wykopaliskowe w strefie Morza Śródziemnego.

Projekt badawczy w Çatalhöyük stanowi integralny element dynamicznego obrazu badań neolitu anatolijskiego. Osadnictwo neolityczne ma charakter wyraźnie wyspowy i jest reprezentowane przez wiele stanowisk tellowych w kilku strefach Anatolii (ryc. 1). Telle powstały dzięki powszechnemu zwyczajowi wznoszenia domów jeden na drugim po uprzednim intencjonalnym opuszczeniu starszego z nich. W rezultacie archeolodzy mają niepowtarzalną możliwość uchwycenia stratygrafii i prześledzenia zmian w kolejnych stuleciach ich zasiedlenia. Efektem szeregu kampanii wykopaliskowych, rozpoczętych w latach $50 . \mathrm{XX}$ w., było rozpoznanie charakteru architektury mieszkalnej i zmian w jej charakterze w większości największych osad ${ }^{5}$.

\footnotetext{
${ }^{5}$ Gérard, Thissen 2002; Özdogan, Başgelen 1999.
} 


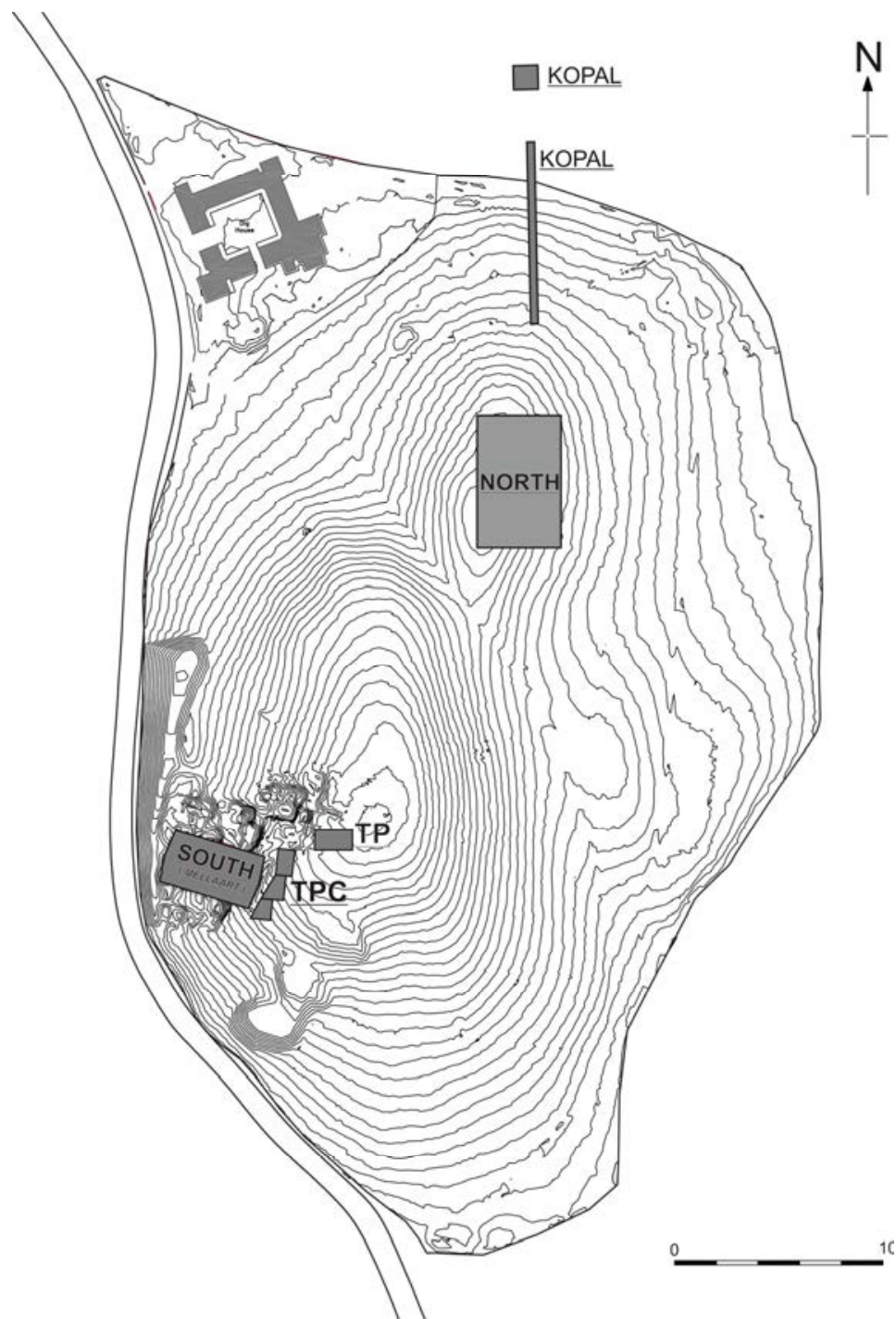

Ryc. 2. Plan warstwicowy Çatalhöyük East z zaznaczoną lokalizacją poszczególnych stref wykopaliskowych (oprac. A. Klimowicz)

Fig. 2. A plan of Çatalhöyük East with excavations areas (by A. Klimowicz)

Intensyfikacja badań wykopaliskowych w ostatnich trzech dekadach pozwoliła na weryfikację dotychczasowych ustaleń $\mathrm{w}$ zakresie różnych aspektów rozwoju neolitycznych społeczeństw Anatolii ${ }^{6}$. Jednym z ich najważniejszych aspektów są

\footnotetext{
${ }^{6}$ Childe $1965,6-104$.
} 
studia nad początkami cywilizacji neolitycznej, w szczególności genezy elementów składowych tzw. pakietu neolitycznego, w skład którego wchodziły: sedentaryzm, udomowienie roślin i zwierząt, nowe technologie oraz wykształcenie się nowego rodzaju organizacji społecznej ${ }^{7}$. W tym zakresie na szczególną uwagę zasługują badania w Göbekli Tepe w południowo-wschodniej Anatolii oraz Așıklı Höyük w Kapadocji ${ }^{8}$. Szczególną uwagę przyciąga Göbekli Tepe z X tys. cal. BC, określane mianem centrum kultowego. Praktyki rytualne odbywały się w przestrzeni wyznaczanej monumentalnymi kręgami kamiennymi. Były one zbudowane na planie koła $\mathrm{z}$ dachem podtrzymywanym przez kamienne, T-kształtne filary, zdobione przedstawieniami ludzi i zwierząt. Göbekli Tepe zostało stworzone przez rozwinięte społeczności łowiecko-zbierackie, które rozpoczęły proces selekcji i intencjonalnego wysiewu niektórych gatunków dzikich traw, co doprowadziło do ich udomowienia i powstania zbóż .

Podobne podstawy gospodarcze posiadała społeczność zamieszkująca Aşıklı Höyük we wschodniej części Środkowej Anatolii 8400-7400 cal. BC (ryc. 1). Jej mieszkańcy zajmowali się pozyskiwaniem obsydianu z bogatych zasobów w sąsiedniej Kapadocji oraz najprawdopodobniej jego dystrybucją ${ }^{10}$. Charakter osady był jednak zupełnie odmienny od Göbekli Tepe ${ }^{11}$. Składały się na nią przylegające do siebie niewielkie pomieszczenia mieszkalne na planie prostokąta i tworzące sporych rozmiarów skupiska poprzedzielane pustymi przestrzeniami. Domy budowano z suszonej cegły mułowej, a mury ustawiano na kamiennych fundamentach. Niektóre z nich miały wyposażenie w postaci pieców, palenisk i zasobników. Pod podłogami niektórych domostw grzebano zmarłych ${ }^{12}$.

\section{HISTORIA BADAŃ W ÇATALHÖYÜK}

Osadę w Çatalhöyük zwykło się określać mianem jednego z najstarszych miast na świecie ${ }^{13}$. Przeprowadzone na szeroką skalę badania jej dynamicznego rozwoju pozwalają na ustalenia początków osady na okres ok. 7400 cal. $\mathrm{BC}^{14}$, a jej końca na ok. 5950 cal. BC ${ }^{15}$.

Pozostałością trwającego bez mała półtora tysiąca lat osadnictwa jest siedemnastometrowe wzniesienie, które ma kształt owalu o długości 450 m i szerokości $275 \mathrm{~m}$

\footnotetext{
${ }^{7}$ Kuijt 2000; Yakar 1991.

${ }^{8}$ Schmidt 2010; Esin, Harmankaya 1999.

${ }^{9}$ Schmidt 2010, 83; Zeist, De Roller 1999.

${ }^{10}$ Esin, Harmankaya 1999, 116.

${ }^{11}$ Esin, Harmankaya 1999; Zeist, De Roller 1999.

${ }^{12}$ Düring, Marciniak 2006.

${ }^{13}$ Mellaart 1967.

${ }^{14}$ Cessford 2001.

${ }^{15}$ Marciniak, Czerniak 2007; Marciniak, Barański, Bayliss et al. [w druku].
} 
(ryc. 2). Na zachód od niego znajduje się niższe wzgórze, które wiąże się z młodszym - chalkolitycznym - osadnictwem. Wznosi się ono na wysokość $7,5 \mathrm{~m}$ ponad płaskowyżem i obejmuje obszar ok. $250 \mathrm{~m} \times 200 \mathrm{~m}$. Charakterystyczna forma tellu z dwoma wzniesieniami przyczyniła się do określania całego kompleksu mianem „rozdwojonego kopca” (z języka tureckiego: Çatal Höyük).

Pierwsze prace na stanowisku zostały podjęte przez brytyjskiego archeologa Jamesa Mellaarta i trwały w latach $1961-1965^{16}$. Ich celem było rozpoznanie charakteru zabudowy tellu i porównanie sekwencji architektonicznych z podobnymi założeniami w innych częściach Bliskiego Wschodu, głównie z Jerycho w dolinie Jordanu i Yumkutepe w Cylicji. Uzyskane wyniki przerosły oczekiwania badaczy. Doprowadziły one bowiem do rozpoznania kilkudziesięciu domów z pochówkami pod ich podłogami. Ściany niektórych z nich zdobione były modelowanymi w tynku płaskorzeźbami, stylizowanymi na bycze lub baranie łby, lamparty oraz postaci ludzkie. Mellaart określił dekorowane $\mathrm{w}$ ten sposób budynki mianem sanktuariów/świątyń, uznając je za centra kultowe ${ }^{17}$. Równie spektakularne były malowidła ścienne z motywami wzorów geometrycznych i scen figuralnych o treści symbolicznej. Te spektakularne odkrycia zapewniły Çatalhöyük poczesne miejsce w pradziejach Bliskiego Wschodu, a samo stanowisko zyskało rangę jednego z symboli światowej archeologii ${ }^{18}$.

Prace badawcze w latach 60 . ubiegłego wieku zostały przeprowadzone na powierzchni ok. 0,4 ha i pozwoliły na rozpoznanie skomplikowanego charakteru zabudowy osady oraz wyróżnienie 13 poziomów jej zabudowy (fazy od XII do 0). Fazy XII-VI odpowiadają neolitowi preceramicznemu, podczas gdy kolejne fazy V-0 związane są z neolitem ceramicznym.

$\mathrm{W}$ połowie lat 90 . wznowiono prace wykopaliskowe na tym słynnym stanowisku w ramach międzynarodowego i interdyscyplinarnego programu „Çatalhöyük Research Project” pod kierunkiem Iana Hoddera z Uniwersytetu Stanforda. Strategia tego 25-letniego projektu zakłada rozpoznanie wielu aspektów funkcjonowania neolitycznej społeczności zamieszkującej Çatalhöyük w kolejnych wiekach $-\mathrm{z}$ wykorzystaniem najnowszych technik i metod badawczych. Do postawionych celów należy m.in. rekonstrukcja paleośrodowiska, systemów gospodarowania i zdobywania pożywienia oraz charakteru specjalizacji, jak również rodzajów wytwórczości, ustalenie charakteru organizacji społecznej i jego związków z praktykami rytualnymi, a także zbadanie relacji z innymi neolitycznymi społecznościami z Bliskiego Wschodu ${ }^{19}$.

Obszerność i różnorodność problematyki badawczej podejmowanej w ramach projektu wymuszają współpracę z wieloma specjalistami. W jego realizacji między-

\footnotetext{
${ }^{16}$ Mellaart 1962, 1963, 1964, 1966, 1967.

${ }^{17}$ Mellaart 1967, 77.

${ }^{18}$ Gimbutas 1989, 1991; Renfrew 2001; Todd 1976.

${ }^{19}$ Hodder 1996, 3.
} 
narodowy zespół archeologów jest wspierany przez przedstawicieli różnych dyscyplin pomocniczych. Zintegrowany charakter procesu badawczego, wymagający systematycznej współpracy wszystkich członków projektu w realizacji podejmowanych zagadnień, jest fundamentem przyjętej metodyki. Jego realizacja jest możliwa dzięki stałej obecności przedstawicieli wielu dyscyplin szczegółowych podczas prowadzonych prac terenowych, co wytwarza unikalne warunki wzajemnej współpracy $w$ trakcie całego sezonu badawczego. Stała kooperacja między archeologami a ekspertami pracującymi w laboratoriach zapewnia ciągłą wymianę poglądów, pozwalającą na tworzenie spójnych interpretacji ${ }^{20}$.

Wykorzystanie wielu nowoczesnych technologii i zastosowanie interaktywnego procesu badawczego umożliwiły rewizję dotychczasowego stanu wiedzy. Jednym z jego ważnych aspektów było precyzyjne ustalenie pozycji chronologicznej Çatalhöyük oraz tempa i dynamiki zmian zachodzących w poszczególnych okresach. Prowadzone dotychczas prace pozwoliły na znaczne uszczegółowienie stratygrafii tellu i stworzenie nowego schematu chronologicznego. W tym celu wykonano ponad 300 oznaczeń radiowęglowych, które zostały następnie poddawane modelowaniu za pomocą statystyk bayesowskich ${ }^{21}$. Metoda ta pozwala na doprecyzowanie chronologii rozmaitych wydarzeń z dokładnością do 20-30 lat i stanowi znaczący postęp w stosunku do tradycyjnie stosowanej chronometrii, pozwalającej na określenie wieku jedynie $w$ dużych przedziałach czasowych ${ }^{22}$. Zastosowanie statystyk bayesowskich jest możliwe $w$ warunkach dysponowania dużą liczbą dat radiowęglowych oraz wielu innych zmiennych mierzących czas, takich jak stratygrafia przedstawiona w postaci macierzy Harrisa czy typologie rozmaitych kategorii artefaktów.

Dotychczas prowadzone badania $\mathrm{w}$ obydwu projektach badawczych koncentrowały się głównie na rozpoznaniu struktury osiedla w okresie neolitu preceramicznego, na który przypada czas największego rozwoju Çatalhöyük. Ustalono, że charakterystyczną formą zabudowy osady były skupiska kilkudziesięciu pojedynczych, przylegających do siebie domów. Reguły dotyczące ich wznoszenia zasadniczo nie ulegały zmianom przez setki lat. Domy były budowane na planie zbliżonym do kwadratu lub prostokąta. Każdy z nich miał odrębne ściany, wykonane z suszonych cegieł. Materiał konstrukcyjny w postaci gliny, mułu oraz trawy pochodził z pobliskiej rzeki Çarşambra i jej rozlewisk ${ }^{23}$.

Organizacja wnętrza domów oraz rozmieszczenie przedmiotów o różnym charakterze zaskakują niebywałą powtarzalnością. Część południowa była związana z codziennymi zajęciami domowymi i kuchennymi. Najważniejszym jej elementem

\footnotetext{
${ }^{20}$ Hodder 2000; Filipowicz 2010.

${ }^{21}$ Bayliss, Farid 2008, 391.

${ }^{22}$ Bayliss, Bronk Ramsay 2004; Bayliss, Bronk Ramsay et al. 2007; Bayliss, Farid 2008.

${ }^{23}$ Mellaart 1962, 1963, 1964, 1966.
} 
był zazwyczaj piec usytuowany pod otworem w dachu, który, spełniając funkcję komina, zapewniał swobodną wentylację wnętrza. W tej części posadowione były często pojemniki na zboże, czasami budowano tam również niewielkie gliniane paleniska. Z kolei w części północnej i wschodniej znajdowały się umiejscowione wzdłuż ścian ławy oraz platformy. Przybierały one formę płaskich, prostokątnych podwyższeń, wzniesionych nieco ponad poziom podłogi. Tę część domu cechuje szczególna staranność wykonania, przejawiająca się przede wszystkim w ich periodycznym ,tynkowaniu", to znaczy nakładaniu kolejnych warstw mułowej lub wapiennej ,gładzi”.

Prostokątne domy z suszonej cegły mułowej, o zróżnicowanej powierzchni (od 11 do $\left.48 \mathrm{~m}^{2}\right)^{24}$, nie miały drzwi wejściowych na poziomie podłogi. Ich funkcję spełniał otwór w dachu, a do wnętrza domu schodzono po drewnianej drabinie. Zwarta zabudowa osady, spowodowana wznoszeniem budynków przylegających bezpośrednio do siebie murami i zakładaniem nowych domów na gruzach starych konstrukcji (nierzadko te ostatnie były wykorzystywane jako fundament), ograniczała przebudowę i rozbudowę pojedynczego budynku ${ }^{25}$. Wnętrza domów były bogato dekorowane, co wskazuje na ich ceremonialny charakter. Jest on dodatkowo podkreślany przez zwyczaj chowania zmarłych członków grupy pod podłogami i platformami. W wielu domach ich liczba sięgała kilkudziesięciu pochówków.

\section{PROJEKT BADAWCZY W ÇATALHÖYÜK}

Przedstawiona powyżej w wielkim skrócie charakterystyka najważniejszych elementów zabudowy Çatalhöyük odnosi się do jego najstarszych dziejów, odpowiadających okresowi neolitu preceramicznego, który zakończył się ok. 6500 cal. BC. Kolejnych pięćset lat rozwoju osady, aż do opuszczenia tellu w początkach VI tys. cal. BC, nie było przedmiotem badań aż do momentu rozpoczęcia prac przez polską misję wykopaliskową ${ }^{26}$.

Badania zespołu Instytutu Prahistorii w Çatalhöyük rozpoczęły się w 2001 r. i trwają nieprzerwanie do dzisiaj. Są kierowane przez prof. Arkadiusza Marciniaka. W latach 2001-2011 prowadzono je w strefie TP (Team Poznań) we współpracy z zespołem Instytutu Archeologii i Etnologii PAN w Poznaniu, a następnie Instytutu Archeologii Uniwersytetu Gdańskiego pod kierunkiem prof. Lecha Czerniaka. Od 2012 r. prace polskiej misji wykopaliskowej w Çatalhöyük są prowadzone wyłącznie przez zespół Instytutu Prahistorii UAM i obejmują nową strefę tellu, określoną mianem TPC (Team Poznań Connection) (ryc. 2). Od początku prac na tym stano-

\footnotetext{
${ }^{24}$ Mellaart 1967, 67.

${ }^{25}$ Düring 2001.

${ }^{26}$ Marciniak, Czerniak 2007.
} 
wisku polski zespół badawczy był w pełni autonomiczny pod względem organizacyjnym i finansowym.

Intensywne prace wykopaliskowe w strefie TP prowadzone były w latach 20012008. Ich cele można ująć w dwa bloki tematyczne. Pierwszy z nich dotyczył rozpoznania skomplikowanego charakteru przekształceń gospodarczych i społecznych, prowadzących do dezintegracji lokalnej społeczności neolitycznej. Obejmuje on w szczególności próby wyjaśnienia i zrozumienia przyczyn, mechanizmów i konsekwencji opuszczenia tellu zamieszkiwanego przez setki lat. Drugim celem projektu była analiza relacji zmian zachodzących w Çatalhöyük pod koniec jego zasiedlenia w stosunku do przekształceń na obszarze Kotliny Konijskiej i w całej Anatolii (głównie w jej części zachodniej i północno-zachodniej). W szczególności uwaga została skupiona na procesach autonomizacji społecznej, zróżnicowania społecznego oraz jego związków ze sferą wierzeniowo-religijną ${ }^{27}$.

Aby realizować tak postawione cele, podjęto badania na szczycie wschodniego wzniesienia, w bliskim sąsiedztwie dawnego wykopu Jamesa Mellaarta. Przyjęta procedura badawcza zakładała wnikliwą i wieloaspektową analizę odkrywanych układów archeologicznych, możliwą do uzyskania dzięki systematycznej współpracy archeologów ze specjalistami różnych dyscyplin. Polski zespół badawczy miał w pełni inderdyscyplinarny charakter, a w jego skład, oprócz archeologów (Joanna Pyzel, Marcin Wąs), wchodzili przedstawiciele innych dyscyplin, takich jak: archeozoologia (Kamilla Pawłowska), paleobotanika (Marek Polcyn) czy antropologia fizyczna (Tomasz Kozłowski). Integralną częścią składową misji wykopaliskowej byli także studenci Instytutu Prahistorii UAM, przede wszystkim ze specjalności archeologii orientalnej i antycznej (Marta Bartkowiak, Malwina Brachmańska, Maciej Chyleński, Agata Czeszewska, Mateusz Dembowiak, Kamila Denisiuk, Patrycja Filipowicz, Katarzyna Harabasz, Jędrzej Hordecki, Łukasz Klima, Arkadiusz Klimowicz, Aldona Kurzawska, Marika Michalak, Ryszard Mikuła, Aleksandra Neumann, Katarzyna Regulska, Klaudia Sibilska, Sabina Siemaszko, Weronika Stosik, Robert Szydlewski, Kinga Vorbrich, Szymon Zdziebłowski). Włączenie młodych adeptów we wszystkie elementy procesu badawczego oraz ich wieloletni udział w projekcie pozwoliły na wykształcenie nowej kadry naukowej, spełniającej pod każdym względem wymogi profesjonalizmu zawodowego na poziomie praktycznym, gabinetowo-interpretacyjnym oraz dydaktycznym.

Rezultaty badań wykopaliskowych w strefie TP okazały się niezwykle znaczące (ryc. 3). Mimo złożonej sytuacji stratygraficznej na szczycie tellu udało się odkryć wiele pozostałości późnoneolitycznej zabudowy stanowiska, które reprezentują zgola odmienny charakter od rozpoznanych dotychczas form osadnictwa ze starszych faz tzw. klasycznego neolitu preceramicznego.

\footnotetext{
${ }^{27}$ Czerniak, Marciniak 2003, 2007; Düring, Marcinak 2006; Marciniak, Czerniak 2007; Filipowicz 2010.
} 

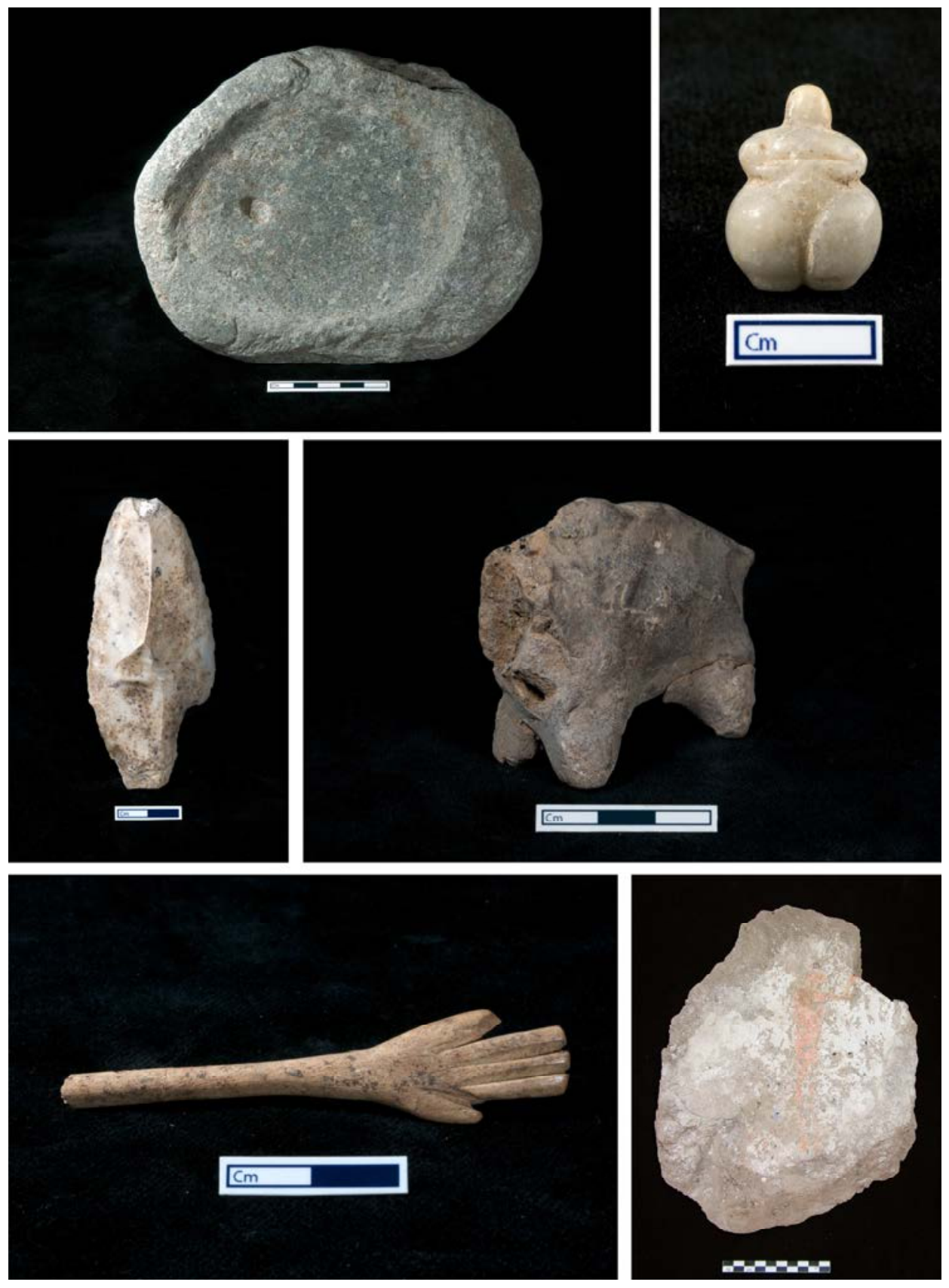

Ryc. 3. Wybór zabytków odkrytych w strefie wykopaliskowej TP (fot. J.P. Quinlan)

Fig. 3. A selection of artefacts from the TP Area (photo J.P. Quinlan) 
Przebadano sekwencję ok. 300-letniego okresu zasiedlenia tellu w strefie TP aż do momentu jego ostatecznego opuszczenia, wydzielając sześć faz osadniczych, począwszy od najstarszej TP-M, a skończywszy na najmłodszej TP-R. Budynki $\mathrm{z}$ ostatniego etapu zasiedlenia, z wyjątkiem wykorzystywania podobnego budulca z suszonych cegieł mułowych, wydają się znacząco odbiegać od uprzednio istniejącego wzorca. Były znacznie większe (ok. 70-80 $\mathrm{m}^{2}$ ), wznoszono je bez nawiązania do wcześniejszych domów, miały zróżnicowany i nieregularny kształt, a ich wewnętrzna organizacja przestrzeni nie nawiązywała do dawniejszego podziału na część południową i północną. Wejście do domów znajdowało się na poziomie podłogi, rozmieszczenie palenisk i pieców w pomieszczeniach było dowolne. Porzucono również praktykę intencjonalnego zasypywania wnętrza domu w momencie jego opuszczenia.

W ostatnich dwóch stuleciach zasiedlenia tellu zupełnej zmianie uległ też obrządek pogrzebowy. Wskazują na to odkryte przez naszą misję wykopaliskową dwie struktury grobowe oznaczone jako 248 oraz 327. Rzucają one zupełnie nowe światło na nieznany do tej pory społeczno-kulturowy aspekt organizacji późnoneolitycznych społeczności Środkowej Anatolii około 6000 cal. BC. Starsza komora grobowa 327 była prostokątną konstrukcją z suszonych cegieł mułowych, zachowaną do wysokości 1,25 m (ryc. 4.A). Wewnętrzne ściany komory (północna, zachodnia i południowa) zostały ozdobione rytym reliefem przedstawiającym motywy spiralne (ryc. 4.B). Powtarzający się motyw dekoracyjny znajdował się na horyzontalnie usytuowanym panelu o szerokości około $35 \mathrm{~cm}$. Cały kontekst odkrytego pomieszczenia, jego cechy architektoniczne oraz obecność przynajmniej 6 szkieletów wskazują, że komora została zbudowana wyłącznie $\mathrm{z}$ przeznaczeniem na cele sepulkralne. Po ok. 75-130 latach bezpośrednio nad nią zbudowano podobny grobowiec 248. Złożono tam szczątki przynajmniej 10 osobników. Dodatkowo w północnej części pomieszczenia umieszczono rodzaj instalacji złożonej z bukranium (górnej części czaszki bydlęcej z możdżeniami) i szkieletu młodej kobiety ${ }^{28}$.

Obydwa obiekty są unikatowymi strukturami, które nie mają odpowiedników w neolicie Bliskiego Wschodu. Pojawienie się konstrukcji mającej ewidentny charakter grobowca $w$ późnych fazach zasiedlenia osady wskazuje na istotne zmiany, jakie tam zaszły z końcem VII tys. cal. BC. Wyznaczają one zasadniczą zmianę w stosunku do trwającej wiele setek lat praktyki chowania zmarłych wewnątrz zamieszkiwanych domów.

Badania w strefie TP dowiodły także bezsprzecznie, że w ostatnich wiekach (c. 6300-5950 cal. BC) doszło do znaczących przemian społecznych i gospodarczych lokalnej społeczności ${ }^{29}$. Była ona zorganizowana w ramach autonomicznych domostw o solidnych podstawach gospodarczych, pozwalających na samodzielne

\footnotetext{
${ }^{28}$ Marciniak, Czerniak 2012; Marciniak, Barański et al. [w druku].

${ }^{29}$ Marciniak 2008; Marciniak, Czerniak 2007, 2012; Düring, Marciniak 2006.
} 


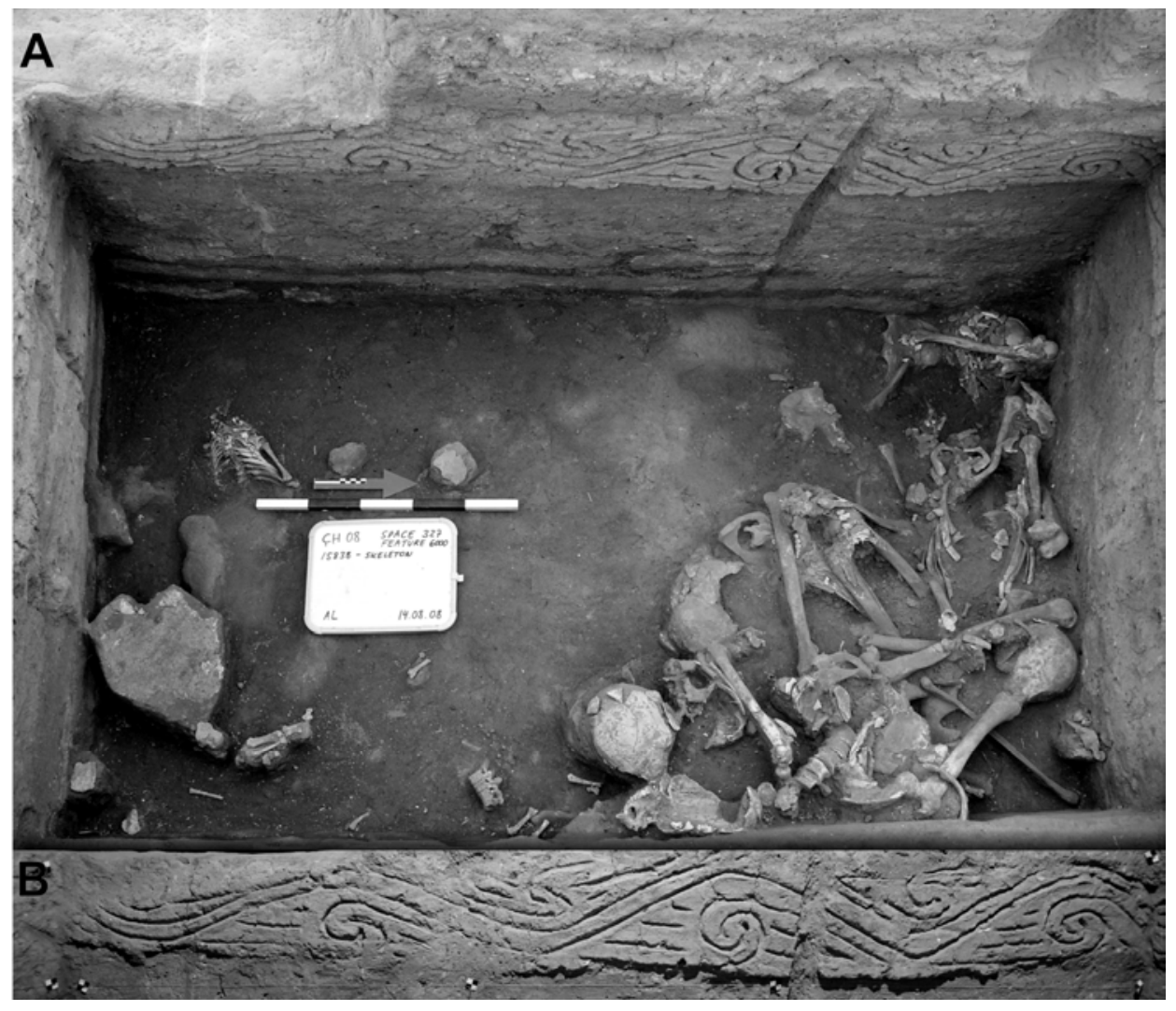

Ryc. 4. Komora grobowa 327: A) rzut poziomy grobowca; B) panel zdobiony rytym reliefem, przedstawiającym motywy spiralne (fot. A. Leszczewicz)

Fig. 4. Burial chamber 327: (A) horizontal view; (B) decorative panel in the form of relief with incised spiral motifs (photo A. Leszczewicz)

zdobywanie i magazynowanie pożywienia. Poprzedni ekstensywny system eksploatacji środowiska i niezbędnych zasobów (drewno, glina) został zastąpiony przez intensywne wykorzystywanie zasobów znajdujących się w sąsiedztwie osady ${ }^{30}$.

Od 2012 r. zespół badawczy Instytutu Prahistorii UAM podjął prace w nowej strefie tellu wschodniego na jego południowo-zachodnim stoku (TPC). Nowy wykop został założony pomiędzy wcześniej badanymi obszarami - TP od strony północno-wschodniej oraz South (badana wykopaliskowo już przez Mellaarta) od strony zachodniej (por. ryc. 2). Decyzja o podjęciu badań w strefie TPC wynikała bezpośrednio $\mathrm{z}$ efektów prac wykopaliskowych $\mathrm{w}$ obydwu wymienionych obszarach. Najważniejszymi celami badawczymi tego nowego projektu jest połączenie

\footnotetext{
${ }^{30}$ Marciniak, Asouti, Doherty, Henton 2013.
} 
sekwencji stratygraficznych ze strefy South z położoną na szczycie tellu sekwencją ze strefy TP, rozpoznanie zmian $w$ architekturze $w$ okresie pomiędzy fazą klasyczną osadnictwa preceramicznego a tą z ostatnich dekad zamieszkiwania osady, analiza systemów gospodarowania i zdobywania pożywienia, eksploatacji środowiska oraz zmieniających się relacji z pozostałymi obszarami Anatolii. Ze względu na wcześniejsze ustalenia, dotyczące charakteru społeczności zamieszkującej osadę w ostatnim okresie jej zasiedlenia, celem trwających prac będzie próba uchwycenia momentu tworzenia się systemu gospodarczego opartego na autonomicznych gospodarstwach domowych i odpowiadającym im zmianom w systemie gospodarczym, w szczególności intensyfikacja, specjalizacja oraz indywidualizacja zajęć związanych z pozyskiwaniem i wykorzystywaniem wielu zasobów naturalnych.

Wyniki dotychczasowych prac badawczych misji anatolijskiej Instytutu Prahistorii UAM w Çatalhöyük, odnoszące się do najmłodszych faz zasiedlenia tellu wschodniego, są niezwykle ważkie. Dowiodły bowiem pojawienia się znaczących przemian zarówno społecznych, jak i gospodarczych. Polegały one na rozpadzie sąsiedzkich wspólnot, stanowiących podstawowy podmiot społeczny w grupach wczesnoneolitycznych, i zastąpieniu ich przez indywidualne domostwa, które stały się autonomiczną jednostką społeczną ${ }^{31}$.

\section{EFEKTY NAUKOWE I DYDAKTYCZNE POZNAŃSKIEJ MISJI WYKOPALISKOWEJ W ÇATALHÖYÜK}

Wyniki badań polskiej misji anatolijskiej były publikowane oraz wielokrotnie przedstawiane przez członków projektu na wielu konferencjach i wykładach, zarówno w kraju, jak i za granicą. Rezultaty każdego sezonu wykopaliskowego były przedstawiane w postaci raportów archiwalnych dostępnych na stronie internetowej projektu $^{32}$. Dotychczas opublikowano cztery artykuły problemowe w renomowanych, recenzowanych czasopismach o cyrkulacji międzynarodowej: Archaeological Dialogues, Antiguity, Anatolian Studies i Documenta Praehistorica ${ }^{33}$. Wyniki badań zostały również przedstawione w Proceedings of the 7th International Congress on the Archaeology of the Ancient Near East (kongres odbył się w Londynie w 2010 r.). Cząstkowe rezultaty zostały także zaprezentowane w wersji popularnej, w czasopiśmie Wiedza i Życie $e^{34}$. Opinia publiczna miała okazję zapoznawać się systematycznie z efektami badań dzięki doniesieniom serwisu naukowego PAP oraz ze specjalnej audycji w II Programie Polskiego Radia (2007). Obecnie trwają prace nad

\footnotetext{
${ }^{31}$ Düring, Marcinak 2006; Marciniak, Czerniak 2007.

${ }^{32}$ Linki internetowe umożliwiające dostęp do sprawozdań TP zostały umieszczone w odrębnej kategorii bibliograficznej: „Raporty z badań wykopaliskowych”.

${ }^{33}$ Düring, Marciniak 2006; Marciniak, Czerniak 2007; Marciniak 2008.

${ }^{34}$ Czerniak, Marciniak 2003.
} 
kompleksowym opracowaniem wyników badań w strefie TP, które ukażą się nakładem Cotsen Institute - University of California at Los Angeles.

Wyniki badań polskiej misji w Çatalhöyük były prezentowane przez jej członków na wielu krajowych i międzynarodowych konferencjach. Należą do nich m.in.: Social and spatial transformations in late Neolithic \& early Chalcolithic in Central Anatolia w Londynie (2006); From Concepts of the Past to Practical Strategies: The Teaching of Archaeological Field Techniques w Pekinie (2006); Leben auf dem Tell als soziale Praxis w Berlinie (2007); $14^{\text {th }}$ Neolithic Seminar. The Neolithic Mind, Populations and Landscapes w Lublanie (2007); Theoretical Archaeology Group Meeting w Nowym Jorku (2008); $42^{\text {nd }}$ Annual Chacmool Conference - Identity Crisis: Archaeology and Problems of Social Identity w Calgary (2009); The $8.2 \mathrm{ka}$ Climate Event and Archaeology in the Ancient Near East w Lejdzie (2010); 7th International Congress on the Archaeology of the Ancient Near East (7ICAANE) w Londynie (2010); The Future of Excavations workshop na Uniwersytecie Browna (2011); $10^{\text {th }}$ International ASWA Meeting. Animal Exploitation in Neolithic Central and Western Anatolia w Brukseli (2010); Times of Change. The Turn from the $7^{\text {th }}$ to the $6^{\text {th }}$ Millennium BC in the Near East and Southest Europe w Berlinie (2011); The $33^{\text {rd }}$ Annual Conference of the Theoretical Archaeology Group (TAG) w Birmingham (2011); The 15th Symposium on Mediterranean Archaeology w Katanii (2011); What's New in the Neolithic w Lund (2013) oraz konferencja American Anthropological Association w Chicago (2013).

Wyniki badań polskiej misji badawczej w Çatalhöyük prezentowano też trzykrotnie na międzynarodowych konferencjach Society for American Archaeology w Vancouver (2008), St. Louis (2010) i Honolulu (2013), czterokrotnie na konferencjach American Schools of Oriental Research w Nowym Orleanie (2009), Atlancie (2010), San Francisco (2011), Baltimore (2013) oraz na konferencji European Association of Archaeologists w Lyonie (2004).

Serię wykładów inspirowanych wynikami polskich badań w Çatalhöyük wygłosił Arkadiusz Marciniak w latach 2009-2011 podczas zajęć w archeologicznej szkole letniej prowadzonej pod auspicjami Unii Europejskiej na Sardynii oraz w trakcie licznych gościnnych wykładów. Odbyły się one w następujących ośrodkach: University of California, Los Angeles w Los Angeles (2006); The Hebrew University w Jerozolimie (2008); W.F. Albright Institute of Archaeological Research w Jerozolimie (2008); seminarium John Templeton Foundation w Konyi (Turcja) (2009); Archaeology Centre - University of Toronto (2009); Department of Anthropology - Tulane University w Nowym Orleanie (2009); Department of Anthropology - University of Manitoba w Winnipeg (2009); Department of Anthropology, Institute for European and Mediterranean Archaeology - University of Buffalo w Buffalo (2010); Archaeological Research Facility - University of California at Berkeley w Berkeley (2012); University of California at Merced w Merced (2012); Department of Anthropology - University of Notre Dame w South Bend (IN) (2013); Clas- 
sics Department - Duke University w Durham (NC) (2013) oraz w ramach spotkań "Friends of Archaeology of Santa Fe (NM)" w Santa Fe (2013).

Osiągnięcia zespołu badawczego były również prezentowane dwukrotnie na polskich konferencjach archeologicznych w Poznaniu oraz dyskutowane czterokrotnie w ramach specjalnych wykładów zorganizowanych przez Instytut Archeologii i Etnologii Polskiej Akademii Nauk, Stowarzyszenie Naukowe Archeologów Polskich oraz muzea archeologiczne w Warszawie i Poznaniu. Były także prezentowane na trzech międzynarodowych konferencjach zorganizowanych w Polsce: Prehistoric Man and his Environment w Poznaniu (2008), 8th International Congress on the Archaeology of the Ancient Near East (8ICAANE) w Warszawie (2011) oraz Neolithic Transformations. The Puzzle of Time: Problems of Absolute Chronology of the Neolithic Societies we Wrocławiu (2012).

Udział w pracach badawczych w Çatalhöyük zaowocował także nawiązaniem bliskiej współpracy z wiodącymi ośrodkami badawczymi w Anatolii, w tym: British Institue of Archaeology in Ankara, American Research Institute (ARIT), obydwa w Ankarze, Deutsches Archäologisches Institut (DAI) w Stambule, jak również z Archeologicznym Instytutem Brytyjskim w Ammanie i Instytutem Albrighta w Jerozolimie. Nawiązano również bliskie kontakty z wieloma tureckimi instytutami uniwersyteckimi, które poskutkowały podpisaniem umów Socrates-Erasmus z UAM, umożliwiając tym samym wymianę studentów oraz odbywanie staży dydaktycznych i naukowych przez doktorantów lub pracowników obydwu stron. Podpisano umowy z angielskojęzycznymi uniwersytetami Bilkent i Middle East Technical University (METU) w Ankarze, a także z Uniwersytetem Seldżuckim w Konyi, Uniwersytetem Anatolijskim w Eskişehir oraz Uniwersytetem Pammukale w Denizili. Zakres merytoryczny prac badawczych podejmowanych przez pracowników tych uniwersytetów daleko wykracza poza problematykę neolitu, co sprawia, że studenci UAM, studiujący archeologię antyczną i orientalną, zajmując się różnymi okresami dziejów Bliskiego Wschodu, mają nieograniczony dostęp nie tylko do znakomicie wyposażonych bibliotek archeologicznych w Ankarze czy Stambule, lecz także możliwość pracy z uznanymi specjalistami z różnych dziedzin archeologii i historii sztuki. Obecność Turcji w wielu programach Unii Europejskiej sprawia, że możliwości nawiązywania różnorodnej współpracy z tamtymi instytucjami archeologicznymi są nieporównywalnie większe niż w przypadku każdego innego kraju z obszaru Bliskiego Wschodu.

Działania anatolijskiej misji badawczej mają też bardzo wymierne konsekwencje dydaktyczne. W badaniach wykopaliskowych dotychczas brało udział 22 studentów Instytutu Prahistorii UAM. Spośród nich siedem osób napisało prace magisterskie, a pięć prace licencjackie ${ }^{35}$. Dodatkowo w trakcie przygotowania jest pięć

\footnotetext{
${ }^{35}$ Tytuły oraz autorzy prac licencjackich i magisterskich znajdują się w odrębnej kategorii bibliograficznej: „Prace magisterskie napisane przez członków ekspedycji badawczej w Çatalhöyük”.
} 
rozpraw doktorskich (Marta Bartkowiak, Agata Czeszewska, Patrycja Filipowicz, Arkadiusz Klimowicz i Katarzyna Regulska), powstających pod kierunkiem prof. Arkadiusza Marciniaka. Poruszają one wiele zagadnień odnoszących się do przemian zachodzących w Anatolii w VII i VI tys. cal. BC.

\section{UWAGI KOŃCOWE}

Niemal piętnaście lat badawczych ekspedycji anatolijskiej to ważny okres w dziejach Instytutu Prahistorii UAM. Ekspedycja ta wyznacza początki nowego etapu w jego dziewięćdziesięcioletniej historii. Jej niewątpliwą zasługą jest inicjacja działań we wschodniej strefie Morza Śódziemnego. Dzięki niej działalność badawcza Instytutu na tym obszarze przeszła swój początkowy etap, a badania w Çatalhöyük na stałe wpisały się w tę historię, stanowiąc jej ważną i integralną część.

\section{BIBLIOGRAFIA}

Bayliss A., Bronk Ramsay Ch., Van Der Plicht J., Whittle A.

2007 Brandshaw and Bayes: Towards a Timetable for the Neolithic, Cambridge Archaeological Journal 17 (1), s. 1-28.

Bayliss A., Bronk Ramsay Ch.

2004 Pragmatic Bayesians a Decade of Integrating Radiocarbon Dates into Chronological Models [w:] Tools for Constructing Chronologies Crossing Disciplinary Boundaries. Lectures Notes in Statistics 177, red. C.E. Buck, A.R. Millard, London, s. 25-41.

Bayliss A., Farid S.

2010 Interpreting Chronology at Çatalhöyük (Neolithic East Mound), Çatalhöyük 2007 Archive Report, s. 390-392.

Cessford C.

2001 A New Dating Sequence for Çatalhöyük, Antiquity 75 (290), s. 717-725.

Childe V.G.

1939 The Orient and Europe, American Journal of Archaeology 43 (1), s. 10-26.

1954 New Light on the Most Ancient East (5th edition), London.

1965 Man Makes Himself (4th Edition), London.

Czerniak L., Marciniak A.

$2003 \quad$ Jak powstało miasto, Wiedza i Życie 4, s. 34-37.

Düring B.S.

2001 Social Dimensions in the Architecture of Neolithic Çatalhöyük, Anatolian Studies 51, s. $1-18$.

Düring B.S., Marcinak A.

2006 Households and communities in the Central Anatolian Neolithic, Archaeological Dialogues 12 (2), s. 165-187.

Esin U., Harmankaya S.

1999 Aşıklı [w:] The Neolithic in Turkey. The Cradle of Civilization, red. M. Özdoğan, N. Başgelen, Istanbul, s. 193-202. 
Filipowicz $\mathrm{P}$.

2010 Sekrety Çatalhöyük, Archeologia Żywa 1 (47), s. 26-32.

Garstang J.

1953 Prehistoric Mersin. Yümük Tepe in Southern Turkey, Oxford.

Gérard F., Thissen L. (red.)

2002 The Neolithic of Central Anatolia. International Developments and External Relations

During the $9^{\text {th }}-6^{\text {th }}$ Millennia Cal BC, Istanbul.

Gimbutas M.

1989 The Language of The Goddess, London.

1991 The Civilization of the Goddess, San Francisco.

Hodder I.

1987 Contextual archaeology. An interpretation of Çatal Hüyük and a aiscussion of the origins of agriculture, Bulletin of Archaeology University of London 24, s. 43-56.

1990 Domestication of Europe. Structure and Contingency in Society, Oxford.

Hodder I. (red.)

1996 On the Surface Çatalhöyük 1993-95, Cambridge.

2000 Towards Reflexive Method in Archaeology: the Example at Çatalhöyük, Cambridge.

Joukowsky M.S.

1996 The Early Turkey. Anatolian Archaeology from Prehistory through the Lydian Period, Dubuque.

Kenyon K.M.

1961 Beginning in archaeology, New York.

1971 An essay on archaeological technique: the publication of results from the excavation of a tell, Harvard Theological Review 64, s. 271-279.

1985 Archaeology in the Holy Land, London.

Kuijt I. (red.)

2000 Life in Neolithic Farming Communities. Social Organization, Identity, and Differentiation, New York.

Lichter C. (red.)

2005 How Did Farming Reach Europe? Anatolian-European relations from the second half of the 7th through the first half of the 6th millennium cal BC (Proceedings of the International Workshop. Istanbul, 20-22 May 2004), Istanbul.

Lloyd S.

1956 Early Anatolia. The Archaeology of Asia Minor Before the Greeks, London.

Marciniak A.

2008 Communities, households and animals. Convergent developments in Central Anatolia and Central European Neolithic, Documenta Praehistorica 35, s. 93-109.

Marciniak A., Czerniak L.

2007 Social transformations in the Late Neolithic and the Early Chalcolithic periods in Central Anatolia, Anatolian Studies 57, s. 115-130.

2012 Çatalhöyük unknown. The late sequence on the East mound [w:] Proceedings of the 7th International Congress on the Archaeology of the Ancient Near East. Volume 1: Megacities \& Mega-sites. The Archaeology of Consumption \& Disposal Landscape, Transport \& Communication, red. R. Matthews, J. Curtis, Wiesbaden, s. 3-16.

Marciniak A., Asouti E., Doherty C., Henton E.

2013 The nature of household in the upper level at Çatalhöyük: smaller, more dispersed and more independent acquisition, production and consumption units. Referat zaprezentowany na 78. dorocznej konferencji Society for American Archaeology w Honolulu. 
Marciniak A., Barański M.Z., Bayliss A., Czerniak L., Goslar T., Southon J., Taylor R.E.

[w druku] Fragmenting Times: interpreting a Bayesian chronology for the late Neolithic occupation of Çatalhöyük East, Turkey, Antiquity 89(343).

Mellaart J.

1962 Excavation at Çatal Hüyük. First preliminary report, 1961, Anatolian Studies 12, s. 41-65.

1963 Excavation at Çatal Hüyük. $2^{\text {nd }}$ preliminary report, 1962, Anatolian Studies 13, s. 43-103.

1964 Excavation at Çatal Hüyük. $3^{\text {rd }}$ preliminary report, 1963, Anatolian Studies 14, s. 39-119.

1966 Excavation at Çatal Hüyük. $4^{\text {th }}$ preliminary report, 1965, Anatolian Studies 16, s. 165-191.

1967 Çatal Hüyük. A Neolithic Town in Anatolia, London.

1975 The Neolithic of the Near East, London.

1978 The Archaeology of Ancient Turkey, London.

Özdoğan M., Başgelen N. (red.)

$1999 \quad$ Neolithic in Turkey. The Cradle of Civilization, Istanbul.

Renfrew C.

2001 Archeologia i język. Łamigłówka pochodzenia Indoeuropejczyków, Warszawa- Poznań.

Sagona A., Zimanski P.

2009 Ancient Turkey, New York.

Schmidt K.

2010 Budowniczowie pierwszych świątýn. Zagadkowy ośrodek kultu myśliwych z epoki kamie-

Todd I.A.

1976 Çatal Hüyük in Perspective, New York.

Yakar J.

1991 Prehistoric Anatolia. The Neolithic Transformnations and the Early Chalcolithic Period, Jerusalem.

Zeist W. van, de Roller G.-J.

1999 Plant remains from Aşıklı Höyük, a Pre-Potery Neolithic site in Central Anatolia, Vegetation History and Archaeobotany 4, s. 179-185.

\section{Raporty z badań wykopaliskowych}

http://www.catalhoyuk.com/archive_reports/2001/ar01_04.html http://www.catalhoyuk.com/archive_reports/2002/ar02_07.html http://www.catalhoyuk.com/archive_reports/2003/ar03_08.html http://www.catalhoyuk.com/archive_reports/2004/ar04_16.html http://www.catalhoyuk.com/archive_reports/2005/ar05_17.html http://www.catalhoyuk.com/downloads/Archive_Report_2006.pdf http://www.catalhoyuk.com/downloads/Archive_Report_2007.pdf http://www.catalhoyuk.com/downloads/RAPOR_Catalhoyuk_2008.pdf http://www.catalhoyuk.com/downloads/Archive_Report_2009.pdf http://www.catalhoyuk.com/downloads/Archive_Report_2012.pdf http://www.catalhoyuk.com/downloads/Archive_Report_2013.pdf

\section{Prace magisterskie napisane przez poznańskich członków ekspedycji badawczej w Çatalhöyük}

1. Ryszard Mikuła, 2006. Ceramika hellenistyczna i rzymska ze stanowiska TP w Çatalhöyük, Turcja. Analiza układów przestrzennych w skali mikroosadniczej, IP UAM.

2. Arkadiusz Klimowicz, 2006. Dynamika wzrostu statusu domów i ich spoteczny kontekst na neolitycznym tellu Çatalhöyük, IP UAM. 
3. Kinga Vorbrich, 2007. Świat dziecka i dziecko w świecie neolitycznej społeczności Çatalhöyük (Turcja), IP UAM.

4. Katarzyna Regulska, 2008. Modele neolityzacji i ich archeologiczna weryfikacja. Model przesuwajacej się fali w kontekście relacji pomiędzy Anatolia potudniowo-wschodnia a środkowa w neolicie, IP UAM.

5. Patrycja Filipowicz, 2009. Recepcja idei matriarchatu i postaci żeńskiego bóstwa $w$ archeologii i społeczeństwie na przykładzie Çatalhöyük, IP UAM.

6. Marta Bartkowiak, 2009. Kulturowa biografia Skull Buildings z preceramicznej osady Çayönu Tepesi w potudniowo-wschodniej Anatolii w kontekście fenomenu budowli ceremonialnych na Bliskim Wschodzie, IP UAM.

7. Agata Czeszewska, 2010. Próba interpretacji malowidet ściennych z neolitycznego tellu Çatalhöyük w perspektywie poststrukturalizmu, IP UAM.

\section{Prace licencjackie napisane przez poznańskich członków ekspedycji badawczej w Çatalhöyük}

1. Mateusz Dembowiak, 2013. Znaczenie dzieci w społeczności neolitycznej osady w Çatalhöyük East. Próba interpretacji grobów dziecięcych, IP UAM.

2. Katarzyna Harabasz, 2013. Dekapitacja i plastrowanie ludzkich czaszek jako przejaw kultu przodków na neolitycznym stanowisku Çatalhöyük, IP UAM.

3. Jędrzej Hordecki, 2013. Weryfikacja systemów typologicznych post-chalkolitycznych pochówków $w$ Çatalhöyük, IP UAM.

4. Aleksandra Neumann, 2013. Ozdoby z muszli w pochówkach Çatalhöyük East, IP UAM.

5. Weronika Stosik, 2013. Problem higieny $i$ warunków sanitarnych oraz ich wptyw na zdrowie populacji Çatalhöyük. Próba stworzenia metodyki dla dalszych badań w tej dziedzinie, IP UAM.

\section{PREHISTORIC ARCHAEOLOGY OF THE EASTERN MEDITERRANEAN AT ADAM MICKIEWICZ UNIVERSITY IN POZNAŃ}

S u m m a r y

As a cradle of many cultures and civilizations, archaeological significance of the East Mediterranean is unquestionable. The region has been of the uttermost importance for the emergence and subsequent development of the Neolithic communities and setting up a new mode of life. Anatolia appears to have played a crucial role in this region as an area in which the original Neolithic traditions got transformed and then passed on to the neighbouring parts of Europe. This special role of Anatolia became evident as early as in the ninth millennium BC and culminated in the emergence of a large settlement at Çatalhöyük on the Konya Plain towards the end of the eighth millennium cal. BC. It has been continuously occupied in the period stretching from ca. 7200 up to $5950 \mathrm{cal}$. BC.

The works at the site began in the early 1960s and were directed by British archaeologist James Mellaart. Spectacular discoveries, including domestic architecture and wall decoration in the form of paintings and reliefs, sub-floor burials and numerous figurines made the site an unquestionable frame of reference for the reconstruction and understanding of complex processes 
taking place in the Near Eastern and European Neolithic alike. The site has been currently investigated within the Çatalhöyük Research Project under the general directorship of Ian Hodder of Stanford University. A team of international scholars has been studying different aspects of the settlement occupation using a wide range of modern techniques. One of the main objectives of these works comprises a comprehensive recognition of the settlement origin in relation to a number of important issues such as the beginnings of the settled life style, emergence of early social organization, and the role of agriculture and domestication of animals. Çatalhöyük has recently been inscribed on the UNESCO World Heritage List.

The developments in the last phases of the settlement occupation, dated back to the final centuries of the seventh millennium BC, had not been studied until the arrival of a team from Poland 15 years ago. The works on the very top of the mound in what began to be referred to as the 'Team Poznań' Area (TP) started in 2001 in cooperation between Adam Mickiewicz University in Poznań and the Polish Academy of Sciences and later University of Gdańsk under the joint directorship of Professor Lech Czerniak and Professor Arkadiusz Marciniak. A new round of works was initiated in 2012 in the neighbouring part of the settlement in the area known as the TP Connection Area (TPC). The now solely AMU project is directed by Professor Marciniak.

Being an integral part of the Çatalhöyük Research Project, both research projects are independent and fully autonomous in terms of their scientific, organizational and financial underpinnings. Major objectives of these ongoing works remain to be focused on recognizing the last period of the settlement occupation (ca. 6400-5950 cal. BC) as well as social and economic transformations of its inhabitants in the period directly preceding the site abandonment. The works revealed a wide range of important changes in settlement organization, internal space of the house, nature of funerary practices, technology of obsidian tools and pottery production as well as acquisition of natural resources and exploitation of local environment. The most spectacular finds comprise two burial chambers with multiple interments. These discoveries are indicative of remarkable transformations in all aspects of the long-lasted Neolithic tradition and are manifested in the emergence of autonomous households on a solid economic footing.

The results of ongoing works have been published and presented in numerous national and international settings. They also led to establishing a close collaboration with numerous leading centres of the Anatolian and Near Eastern Neolithic studies. The project at Çatalhöyük comprises also an active participation of students leading to completion of numerous Bachelor, Master and Doctorate dissertations.

Being the first excavation works in the East Mediterranean ever conducted by scholars from Adam Mickiewicz University, the Çatalhöyük project has already significantly contributed to the development of Mediterranean archaeology in our Alma Mater, both in terms of academic excellence and development of didactic curricula. 